\title{
ELLJ
}

\section{Economic security \& the regulation of gig work in California: From AB5 to Proposition 22}

European Labour Law Journal 2022, Vol. I3(I) 5I-65 (C) The Author(s) 2021 Article reuse guidelines: sagepub.com/journals-permissions DOI: $10.1177 / 20319525211063$ III journals.sagepub.com/home/ell

$@$ SAGE

\section{Veena B. Dubal}

Professor, University of California, Hastings College of the Law

\begin{abstract}
Employment is the primary legal and political means to address economic inequality in the United States. With the evisceration of the welfare state, employment is also key to democratic outcomes. Despite this, self-employed work deployed by labour platforms like Uber has grown in recent years. What can we learn from worker demands and recent regulatory attempts to clarify and extend who is covered by employment protections? Based on a decade of legal and ethnographic research in the state of California, I situate the legal and regulatory history of labour platform work in the context of platform workers' experiences and responses to the insecurities and poverty promulgated by their putative status as independent contractors. In highlighting this history, I argue that self-organised labour platform workers were critical to the passage of a state law (AB5) that would have forced companies to treat them as employees - with access to predictable living wages, unemployment insurance, workers' compensation, and health insurance, among other safety net protections. Finally, I show how, leveraging tremendous structural and instrumental power, the major labour platform companies, in the middle of the global Coronavirus pandemic, sponsored a successful referendum on $A B 5$, and lay out the anti-democratic implications of the referendum's passage.
\end{abstract}

\section{Keywords}

Labour platform work, gig economy, employee status, contingent labour, Uber, precarious work, self-employment

\section{Introduction}

Poverty is not a suspect classification under the U.S. Constitution, but it is an affront to life and dignity and to democracy more broadly. With the evisceration of the U.S. welfare state and

\section{Corresponding author:}

Veena B. Dubal, Professor, University of California, Hastings College of the Law

Email: dubalv@uchastings.edu 
judiciary's deference to political outcomes in the area of 'economics and social welfare', ${ }^{1}$ employment is the primary legal and political means to address economic inequality. ${ }^{2}$ In turn, employment is - for better or for worse - key to democratic outcomes in the U.S. It provides access to the tools for basic sustenance: the minimum wage and overtime payments; health insurance; and safety net protections, such as workers' compensation, disability benefits, unemployment insurance, and even the right to organize and collectively bargain (see Table 1).

The capacity of individuals in the U.S. to participate in life and partake in politics, depends, in no small part, on their status as employees. In the words of political theorist Judith Shklar: 'We are citizens only if we "earn". 3 Yet, since at least the 1970s, the capacity of U.S. workers to earn a sustainable income through work has been curtailed by the proliferation of contract labour work conducted outside the regulatory framework of employment. ${ }^{4}$ In recent years, this kind of contract work has grown both offline and online, through on-demand and crowdsourcing labour platforms which rely on putative independent contractors. ${ }^{5}$ Workers in this context are paid by the piece and not for all the time they spend working.

The potential for labour platforms which rely on non-employee labour to exacerbate poverty and degrade democracy looms large in debates about the future of work and of workers in the U.S. Accurate estimates of this informal digital labour market are difficult to ascertain, but data from U.S. bank accounts suggests that $4.5 \%$ of U.S. families participated in the online platform economy in 2017 , up from roughly $1.8 \%$ in $2015 .^{6}$ These percentages have undoubtedly grown in the Covid-19 pandemic, as evidenced by the exponential growth of the food delivery labour market. While the number of app-based workers remains comparatively small, both this sector's rapid growth and the potential for industries to reproduce this independent contractor model makes it an area worthy of urgent regulatory attention. ${ }^{7}$

1. Loffredo, Stephen, 'Poverty, democracy and constitutional law', University of Pennsylvania Law Review 141, no. 4 (1993): 1277-1389, 1278-1290.

2. Dubal, V. B. 'Wage Slave or Entrepreneur: Contesting the Dualism of Legal Worker Identities', Calif. L. Rev. 105 (2017): 65,67 .

3. Shklar, Judith N. American citizenship: The quest for inclusion. Harvard University Press, 1995, 416.

4. Dubal, V. B. 'Wage Slave or Entrepreneur: Contesting the Dualism of Legal Worker Identities', Calif. L. Rev. 105 (2017): 65; Collier, Ruth Berins, V. B., and Christopher Carter, 'The regulation of labour platforms: the politics of the Uber economy', Working Paper (2017), 3-5. Available at https://brie.berkeley.edu/sites/default/files/reg-of-labour-platforms.pdf.

5. Id. For the purposes of this article, I define labour platforms as those that connect requestors with workers for specific tasks, exerting differing amounts of control over the workers and completion of the tasks.

6. Out of a de-identified sample of 39 million bank accounts, J.P. Morgan issued statistics in March 2018 suggesting that $4.5 \%$ of U.S. families participated in the online platform economy in the previous year. This was up from roughly $1.8 \%$ in 2015. The majority of this growth was in the on-demand transportation sector. While the number of workers in this sector appears to continue to grow, their net earnings have decreased. Cf. Farrell, Diana, Fiona Greig, and Amar Hamoudi, 'The Online Platform Economy in 2018: Drivers, Workers, Sellers and Lessors', JPMorgan Chase Institute. 2018. Available at: https://www.jpmorganchase.com/corporate/institute/document/institute-ope-2018.pdf.

7. Because the U.S. Bureau of Labor Statistics does not count contingent or alternative employment relations, we do not have a good sense of how many people do work in the market created by labour platforms. The best estimates come from J.P. Morgan which uses Chase bank account data to track supply side labour participation and earnings in the 'online platform economy'. In J.P. Morgan's study, the online platform economy is defined to include 128 companies, including both 'labour platforms' and 'capital platforms'. They meet the following criteria: '(1) Connect independent suppliers to customers; (2) Mediate the flow of payment from customer to supplier (3) Allow participants to enter and leave the market whenever they want.' Cf. Farrell, Diana, Fiona Greig, and Amar Hamoudi, 'The Online Platform Economy in 2018: Drivers, Workers, Sellers and Lessors', JPMorgan Chase Institute. 2018. Available at: https://www.jpmorganchase. com/corporate/institute/document/institute-ope-2018.pdf . 
Table I. Defining 'Employees' Under U.S. Federal \& State Laws: An Approximate Summary, *federal laws in bold

\begin{tabular}{|c|c|c|}
\hline Legal Test & Dispositive Factors & Employment Protection/Benefit \\
\hline $\begin{array}{l}\text { I. Common Law of } \\
\text { Agency Test }{ }^{\prime \prime}\end{array}$ & $\begin{array}{l}\text { [Alleged] Employer's Control over } \\
\text { "Means and Manner" of Worker's } \\
\text { Work" }^{12}\end{array}$ & $\begin{array}{l}\text { Protection from } \\
\text { Disscrimination under Title VII of } \\
\text { the Civil Rights Act } \\
\text { Protection under the Age } \\
\text { Discrimination in Employment Act } \\
\text { (ADEA) } \\
\text { Protection under the } \\
\text { Employee Retirement Income } \\
\text { Security Act (ERISA) Protection under } \\
\text { State Worker's Compensation Laws }\end{array}$ \\
\hline $\begin{array}{l}\text { 2. Economic } \\
\text { Realities Test }{ }^{13}\end{array}$ & $\begin{array}{l}\text { A. Degree of control exercised by the } \\
\text { alleged employer; } \\
\text { B. Extent of the relative investments } \\
\text { of the [alleged] } \\
\text { C. Degree to which the "employee's" } \\
\text { opportunity for profit and loss is } \\
\text { determined by the "employer"; } \\
\text { D. Skill and initiative required in } \\
\text { performing the job; and } \\
\text { E. Permanency of the relationship. }\end{array}$ & $\begin{array}{l}\text { Wage and Hour Protections under } \\
\text { the Fair Labor } \\
\text { Standards Ace }{ }^{14} \text { (ELSA) } \\
\text { Protections under the Family } \\
\text { Medical Leave Act (FMLA) } \\
\text { Benefits under the Social Security } \\
\text { Act (SSA) }\end{array}$ \\
\hline $\begin{array}{l}\text { 3. Entrepreneurial } \\
\text { Potential Test }\end{array}$ & $\begin{array}{l}\text { Evaluation of control "through the } \\
\text { prism of [the workers'] } \\
\text { entrepreneurial opportunity" for } \\
\text { economic gain. }\end{array}$ & $\begin{array}{l}\text { Protection for Collective Organizing } \\
\text { \& Bargaining under National Labor } \\
\text { Relations Act }\end{array}$ \\
\hline 4. ABC Test & $\begin{array}{l}\text { A. The worker is free from control or } \\
\text { direction in the performance of the } \\
\text { work. } \\
\text { B. The work is done outside the usual } \\
\text { course of the company's business and } \\
\text { is done off the premises of the } \\
\text { business. } \\
\text { C The worker is customarily engaged } \\
\text { in an independent trade, occupation, } \\
\text { profession, or business. }\end{array}$ & $\begin{array}{l}\text { California Employment Law Protections, } \\
\text { including wage and hour laws, } \\
\text { unemployment insurance laws, and } \\
\text { workers' compensation laws. }{ }^{16} \\
\text { Protection under State Unemployment } \\
\text { Insurance Laws }{ }^{17}\end{array}$ \\
\hline
\end{tabular}

Law and policy discussions of work in the online sector have focused on the application of employment protections to the growing number of workers who get jobs through labour platforms, both on-demand and crowdsourced. The central question in this debate has been what test best captures employment status. To date, the test most frequently used to make this determination under U.S. labour and employment laws is the traditional 'right to control' test, derived from the common law of agency. As I have shown elsewhere, this test was borrowed from tort law in the mid- $20^{\text {th }}$ century and infused into the analysis of who benefits from U.S. safety net protections. ${ }^{8}$

8. Dubal, V. B. 'Wage Slave or Entrepreneur: Contesting the Dualism of Legal Worker Identities', Calif. L. Rev. 105 (2017b): 65. 
If regulators and judicial bodies take a purposive approach to applying U.S. employment and labour laws, the control test is poorly suited for analytical use in the labour platform context. While on-demand workers like Uber drivers and Instacart shoppers are still very likely employees under the right to control analysis, ${ }^{9}$ workers who service crowdsourcing platforms such as Amazon Mechanical Turk (AMT), which does not exert the same level or kind of control over wages or conditions of work, are less likely to fall under the laws' protections. ${ }^{10}$ Furthermore, across the on-demand and crowdsourcing contexts, the control test does not account for the ways in which labour platform businesses can alter their business models to evade the employment and labour regime. Over 40 years of dispute and litigation over employment status in the offline labour market has demonstrated that companies with the financial ability to reshape their businesses in response to legal decisions under the control test will do so. ${ }^{11}$ This tinkering with 'control' to evade employment and labour law liabilities is particularly easy when that control is exerted digitally.

The offline misclassification of workers in industries as diverse as construction, beauty, taxi, and trucking has spurred a four-decade debate in the U.S. on the best test to capture employment status. Under U.S. law, employment law is fragmented, and different tests are used to determine employment status for the various rights and entitlements ascribed to 'employees' (see Table 1). For example, a worker could be classified as an employee for wage purposes, but an independent contractor under collective bargaining laws. Businesses have traditionally pushed to narrow the application of employment rights by advocating the application of versions of the control test that take into account 'entrepreneurial potential'. Workers' advocates have sought to extend the reach of employment laws through use of the 'economic realities' test and, more recently, the expansion of the 'ABC' test. The economic realities test, which analyses how economically reliant a putative employee is on her employer, has, like the control test, produced inconsistent results. The ABC test, on the other hand, integrates the ability of companies to re-engineer their business models into an

9. Indeed, courts in New York and Pennsylvania have determined that Uber drivers are employees under variations of the control test. These legal determinations were made in light of the extreme forms of the algorithmic control administered by Uber, including control over wages, powers over the dissemination of work, and the ability to terminate workers.

10. Mechanical Turkers are paid per task rather than per hour. This means that the account of time a worker spends finding a task, choosing a task, waiting for a task, and updating a task to meet the demands of a requestor goes unpaid. Pew Research survey found about one-half of Turkers make less than USD5 per hour. Nearly two-thirds of the tasks posted pay 10 cents or less. Cf. Hook, Lesley, 'The Humans Behind Mechanical Turk', Financial Times. October 26, 2016. Available at https://www.ft.com/content/17518034-6f77-11e6-9ac1-1055824ca907. Requesters on AMT are empowered to define most terms and conditions of Turkers' work. AMT, however, does prohibit Turkers from using automated devices to complete the work and from contracting with requestors outside the platform.

11. See my article on how FedEx Home Delivery used an appellate court decision, which found the drivers to be employees, to re-engineer their business model and make their workers look more like putative independent contractors. 'When Estrada [v. FedEx] was decided [ by the $9^{\text {th }}$ circuit in 2007 in favor of plaintiff workers], many commentators understood it as having a potentially far-reaching consequence for FedEx drivers, but instead of abiding by the spirit of the decision and paying their drivers as employees, FedEx responded to Estrada by eliminating their single-route contracts. In late 2007, the company shifted all their California work to the "multi-work area" business model. Many single-route drivers were forced to purchase other routes [in a bid to show the company exerted little control over these workers] and more than 1,000 single route drivers were not renewed. FedEx acknowledged that this action was taken in response to the Estrada decision.' [Check to ensure I have put the quotation mark in the right place, as it was missing] Cf. Dubal, V. B. 'Winning the Battle, Losing the War: Assessing the Impact of Misclassification Litigation on Workers in the Gig Economy', Wis. L. Rev. (2017): 739, 789. 
analysis of employment status. See Table 1 for a substantive review of these different tests and the employment and labour law protections for which they are utilised.

AB5, a Bill which was signed into law in California in September 2019 and came into effect on January 1 2020, was the first new state law in the U.S. to address misclassification in the online and offline economies by extending the $\mathrm{ABC}$ test to all state employment laws, including protections for the minimum wage, overtime, unemployment insurance, and workers' compensation. AB5 most clearly pulled workers who had previously been misclassified as independent contractors back under the 'employee' umbrella by codifying the presumption of employee status under state law and putting forth an exacting, conjunctive test that hiring entities must meet if they wish to engage workers as non-employees. Unlike traditional versions of the control test and nascent forms of the test of entrepreneurial potential (see Table 1, as articulated in FedEx v. NLRB, 563 F. 3d 492 (2009) and extended in Supershuttle DFW, Inc., 367 NLRB No. 75 (2019)), California's $\mathrm{ABC}$ test presumes that workers are employees and puts the burden on the hiring entity to prove otherwise. The simplicity of the test also makes it easier for regulators to enforce employment laws.

Because labour platforms like Uber have posed risks to employment regimes and the security of workers all over the world, and AB5 did not include an exemption for these companies (despite intense lobbying by the companies), the law was internationally lauded ${ }^{12}$ and states across the U.S. sought to replicate it. ${ }^{13}$ Building on the law's passage, the U.S. House of Representatives passed the Protecting the Right to Organizing Act (PRO Act), which adopted the ABC test for the purposes of determining who is an employee for purposes of collective organising and bargaining. ${ }^{14}$ The PRO Act was never introduced in the Senate. However, President Biden's administration has stated an intention to work with Congress 'to establish a federal standard modeled on the ABC test for all labour, employment, and tax laws'. 15

Soon after the passage of AB5, California labour platform companies Uber, Lyft, Postmates (now owned by Uber), DoorDash, and Instacart invested USD203 million in a ballot initiative campaign - the most expensive in U.S. history. The initiative, which the companies wrote, and which became known as Proposition 22, created exemptions from AB5 for 'Transportation Network Companies' (TNC) and 'Delivery Network Companies' (DNC). ${ }^{16}$

12. See, e.g., the press release of the International Transport Workers' Federation which calls for AB5 to be the inspiration for global rules to govern the gig economy. Cf. International Transport Workers' Federation. California AB5 Law: Now We Need a Global Law for 'Gig Workers.' Press Release, September 12, 2019. Available at https://www.itfglobal.org/ en/news/california-ab-5-law-now-we-need-global-law-gig-workers.

13. As of January 2020, New York, New Jersey, and Illinois, for example, were all considering a version of AB5. Cf. Rosenberg, Eli, 'Gig economy bills move forward in other blue states, California leads the way', Washington Post (2020). Available at https://www.washingtonpost.com/business/2020/01/17/gig-economy-bills-move-forward-otherblue-states-after-california-clears-way/.

14. See https://rules.house.gov/bill/116/hr-2474.

15. See https://joebiden.com/empowerworkers/.

16. In Prop 22, the sponsoring companies defined 'Delivery Network Company' (DNC) as 'a business entity that (1) maintains an online-enabled application or platform used to facilitate delivery services within the State of California on an on-demand basis, and (2) maintains a record of the amount of engaged time and engaged miles accumulated by DNC couriers.' This is the first time such a company has existed under California laws and regulations. Since 2014, 'Transportation Network Company' (TNC) has been defined by the California Public Utilities Commission as: 'A sub-type of charter-party carrier providing transportation services using an online-enabled platform to connect passengers with drivers using their personal vehicles.' 
Table 2. Overview of Labour Rights Prior to Prop 22 \& After Prop 22

\begin{tabular}{|c|c|}
\hline $\begin{array}{l}\text { Labor Protections that CA TNC \& DNC Drivers } \\
\text { Were Entitled to BEFORE Passage of Proposition } 22\end{array}$ & $\begin{array}{l}\text { Labor Protections Proposition } 22 \\
\text { Provides for CA TNC and DNC Drivers }\end{array}$ \\
\hline $\begin{array}{l}\text { Minimum Wage + Overtime at } 150 \% \text { of minimum } \\
\text { wage (over } 8 \mathrm{hrs} / \text { day, } 40 \mathrm{hrs} / \text { week) }\end{array}$ & $\begin{array}{l}\text { Minimum Pay for "Engaged Time" Only, No } \\
\text { Overtime } \\
\text { [See footnote } 22 \text { for definition of engaged time] }\end{array}$ \\
\hline $\begin{array}{l}\text { Expense Reimbursement for all Expenses incurred } \\
\text { while working (insurance, cellphone, etc.), } \\
\text { including } \$ .57 \text { per mile mileage reimbursement }\end{array}$ & $\begin{array}{l}\text { No Reimbursement for Expenses, except } \$ .30 \text { per } \\
\text { mile mileage reimbursement for "Engaged Time" } \\
\text { Only }\end{array}$ \\
\hline $\begin{array}{l}\text { No-fault workers' compensation coverage for work- } \\
\text { related injuries }\end{array}$ & \\
\hline $\begin{array}{l}\text { Three days of paid leave for illness or care of family - } \\
\text { up to } 10 \text { in some cities; } \\
\text { additional COVID- } 19 \text { leave in some cities }\end{array}$ & \\
\hline $\begin{array}{l}\text { Unemployment Compensation for up to } 26 \text { weeks of } \\
\text { no-fault job loss }\end{array}$ & \\
\hline Lifetime access to wage replacement if injured & $\begin{array}{l}\text { Up to two years of access to wage replacement if } \\
\text { injured }\end{array}$ \\
\hline Health insurance under the Affordable Care Act & $\begin{array}{l}\text { Healthcare subsidies for those already insured } \\
\text { (unless covered by Medicaid), determined based } \\
\text { on "Engaged Time" }\end{array}$ \\
\hline
\end{tabular}

The companies misrepresented to both voters and drivers what the initiative would do. Voters were bombarded, for example, with television, radio, internet, email, and in-app messaging that said that Prop 22 would give workers a minimum wage, more benefits, and that drivers would lose their 'flexibility' if Prop 22 did not pass. In reality, the initiative legally sanctioned the workers' independent contractor status, stripped workers of protections owed to them by law, and provided very limited benefits in return (see Table 2). Prop 22, for example, denies workers a time-based minimum wage and overtime protections, and instead creates a payment floor during 'engaged time" ${ }^{17}$ because workers are not paid when awaiting assignments, they have no guaranteed minimum wage. A study by University of California, Berkeley economist Michael Reich that examined the financial and economic consequences of employee status on Uber and Lyft drivers confirmed that driver flexibility would not be affected. ${ }^{18}$ We can expect more companies that do logistics work to re-invent themselves to fit the definitions of TNCs and DNCs, thereby lowering costs associated with labour.

17. Prop 22 defines engaged time as 'time spent by the worker after they accept and complete a ride or delivery request is paid, not any time waiting for rides or delivery requests while logged on to the app and ready to work.' Engaged time is determined both by demand and by the companies' algorithmically-determined allotment of work to individual workers. Accordingly, workers cannot predict their income, and if demand is really low, as during a pandemic, they can lose money after working a shift.

18. Reich, Michael, 'Pay, Passengers, and Profits: Effects of Employee Status for California TNC Drivers', Institute for Research on Labour and Employment Working Paper \#107-20. October 2020. Available at https://irle.berkeley.edu/ files/2020/10/Pay-Passengers-and-Profits.pdf. 
What implications might Prop 22's exemptions hold for the relationship between work, poverty, and democracy more broadly? And what lessons can lawmakers and enforcers across the world learn from the passage of both AB5 and Prop 22 in California? In the following sections, I situate this regulatory history amidst the broader emergence of precarious labour platform work in California and workers' experiences and responses to the insecurities associated with it. In the conclusion, I discuss the potential repercussions of Prop 22 beyond California, what steps federal lawmakers may take to preempt the law in California, and what lessons may be learned from the California story.

\section{Sharing or taking? The emergence of precarious platform labor}

To understand the significance of AB5 and Proposition 22 in the broader political and economic context, we must understand how the precarious labour trends that prompted both laws initially proliferated. Labour platform companies Uber and Lyft first appeared on the streets of San Francisco in the shadows of the Great Recession. They operated under the guise of sharing and trust-building and launched to a captive audience. In a period of heightened unemployment and distrust in government (on both the left and the right), the companies capitalised on the public appetite for easily accessible jobs and economic re-making to introduce 'disruptive' business models built on putative independent contractor labour. Uber and Lyft (which paved the ideological way for numerous labour platform companies that followed in their suit) provided traditional taxi services outside of traditional regulatory frameworks ${ }^{19}$ at rock-bottom, venture-capital subsidised prices. ${ }^{20}$ They argued that their technology platforms produced not work, but community, and their public relations message was that they did not employ people; they empowered them.

Belying this seductive narrative are anticompetitive business practices and insecure work. The labour platforms set fares, control worker behavior through algorithms, ${ }^{21}$ and unilaterally (and sometimes inexplicably) terminate workers. The companies, building on four decades of offline business practices that slough off labour costs through misclassification, claim to facilitate microentrepreneurship. In reality, individual workers bear all the traditional risks of business. ${ }^{22}$ In the Uber and Lyft context, for example, gig workers provide their own car, phone, hybrid car insurance and gas, but have very little to no control over the business itself. Unlike small businesspeople, most gig workers cannot negotiate prices, the terms of their work, or even develop their own client base. Although the companies tout flexibility, the time schedules of workers are highly incentivised by price structures; and drivers are informed at the beginning of the week the time frames, based on data analytics collected by drivers in previous weeks, during which the companies anticipate demand. In order to make money, drivers must work during these particular, highdemand hours. Full-time drivers frequently work more than 60 hours a week, and even in busy metropolitan areas, after accounting for expenses, their hourly incomes fall well below the

19. Dubal, V.B. 'The Drive to Precarity: A Political History of Work, Regulation, \& Labour Advocacy in San Francisco's Taxi \& Uber Economics', Berkeley J. Emp. \& Lab. L. 38 (2017): 73, 119-134.

20. Dean, Sam, 'Uber Fares are Cheap, Thanks to Venture Capital', Los Angeles Times (May 11, 2019). Available at https:// www.latimes.com/business/technology/la-fi-tn-uber-ipo-lyft-fare-increase-20190511-story.html

21. Scheiber, Noam, 'How Uber uses psychological tricks to push its drivers' buttons', The New York Times (2017). Available at https://www.nytimes.com/interactive/2017/04/02/technology/uber-drivers-psychological-tricks.html

22. Dubal, V. B. 'Wage Slave or Entrepreneur: Contesting the Dualism of Legal Worker Identities', Calif. L. Rev. 105 (2017): 65, 119-134. 
minimum wage of the cities in which they work. Despite aggressive regulatory arbitrage, almost a decade since their founding, most of the large labour platform companies have not turned a profit.

\section{From failures to regulate to dynamite Dynamex}

Despite growing complaints from workers and organised driver protests, regulators in U.S. states failed to enforce existing employment laws against labour platform companies, and in some states, they have affirmatively legalised their independent contractor business models. ${ }^{23}$ This culture of political acquiescence began at ground zero in San Francisco. When Lyft hit the streets of San Francisco in 2012, the California Public Utilities Commission (CPUC, a state regulatory agency) issued a cease and desist order, arguing that the company was operating illegally. ${ }^{24}$ With this state order in effect, then-San Francisco Mayor Ed Lee (who hoped to attract technology companies to establish themselves in the city, rather than in Silicon Valley) took a different municipal approach, commending the emergence of Lyft and Uber, launching a Sharing Economy Working Group, and pronouncing June 132013 'Lyft Day'.

The CPUC eventually changed course and began a rule-making process to legalise the companies, noting that the agency sought to 'foster innovation'. ${ }^{25}$ By regulating this industry state-wide, the agency effectively pre-empted California cities from enacting local regulations. ${ }^{26}$ This meant that workers and regulators would be more disconnected and that the policy-making process would be more opaque. Hoping that the courts would address the misclassification concern, the CPUC wrote rules that were silent on labour issues. ${ }^{27}$

Around the same time, a number of class action lawsuits were filed by plaintiffs' attorneys alleging the misclassification of workers by Uber and Lyft. But ultimately, the class actions' effectiveness as enforcement mechanisms were stymied by arbitration clauses and the U.S. Supreme Court's decision in Epic Systems v. Lewis. (138 S.Ct. 1612 (2018)). Epic Systems made it clear that under U.S. law, arbitration agreements in labour contracts that contained prohibitions on class actions were legal and not a violation of the National Labour Relations Act as some lower courts had held. Thus, class actions against gig companies in which classes of workers had been certified by courts were subsequently de-certified. The only path to effective enforcement of labour laws, then, could be conducted by (often under-resourced) state actors.

One month before Epic Systems was decided, the California Supreme Court decided Dynamex v. Superior Court of Los Angeles (4 Cal.5th 903 (2018)). Dynamex changed California law and the conversation around employee rights in the gig economy in the U.S. In Dynamex, which addressed

23. Collier, Ruth Berins, V. B. Dubal, and Christopher L. Carter, 'Disrupting regulation, regulating disruption: The politics of Uber in the United States', Perspectives on Politics 16, no. 4 (2018): 1-1, 7-8

24. Ibid., 14.

25. Ha, Anthony, 'California Regulator Passes First Ridesharing Rules, A Big Win for Lyft, Sidecar, and Uber', TechCrunch (September 19, 2013). Available at https://techcrunch.com/2013/09/19/cpuc-ridesharing-regulations/

26. Smith, Rebecca, Jo Borkholder, Mariah Montgomery, and Maiya Saika Chen, 'Uber State Interference: How TNCs Buy, Bully, and Bamboozle Their Way to Deregulation,' National Employment Law Project (January 18, 2018). Available at https://www.nelp.org/publication/uber-state-interference/

27. Notably, they were also silent on supply (the number of Uber and Lyft vehicles operating at any given time) and on prices, two issues that had been regulated in the taxi industry for over a century (see, generally, Dubal, V.B. 'The Drive to Precarity: A Political History of Work, Regulation, \& Labour Advocacy in San Francisco's Taxi \& Uber Economics', Berkeley J. Emp. \& Lab. L. 38 (2017): 73). 
the classification of drivers for an offline delivery company, the Court wrote that the purpose of California wage laws was to 'raise living standards' for California workers and their families. ${ }^{28}$ The decision noted how easy it was for companies to manipulate their business models to avoid responsibility to workers under the existing legal test for employment. To better address this growing issue, the Court revised the state's analysis of employee status under wage orders.

The Court in Dynamex decided that all California workers are employees for wage orders as a matter of law. The decision also stated that if a hiring entity wants to use independent contractor labour, the entity must prove the workers are contractors by fulfilling the terms of a conjunctive, tripartite test - the ABC test. Practically, this analysis takes place at the time of enforcement: when a worker initiates a lawsuit, when the Labour Commissioner brings a field enforcement investigation, or when a city attorney or state attorney general decides to sue. ${ }^{29}$

The ABC test (see Table 1) differs from the one outlined in S.G. Borello \& Sons, Inc. v. Department of Industrial Relations (48 Cal. 3d 342 (1989)), which for three decades had been used to determine employee status under most California laws. Like most tests to determine employee status in the U.S., the Borello test was rooted in a multifactor analysis of control: how much control did the hiring entity wield over the means and manner of the worker's performance? The more control that the hiring entity had, the more likely it was that the worker was an employee. While Borello was generally considered worker-friendly, it was riddled with problems. For one, the test left too much room for subjective analysis, such that different judges could come to different decisions on the same set of facts. ${ }^{30}$ Additionally, over the years, companies had found ways to use the test as a roadmap to avoid liability. ${ }^{31}$

Rather than looking to an analysis of control in the workplace as a mark of employee status, the $\mathrm{ABC}$ test is enforcement-oriented, focusing on the core business performed by the hiring entity. While this emphasis does not preclude companies from attempting to evade employment status by reimagining what is core to their business, it makes it much harder. For example, in California, Uber's various post-AB5 changes (namely, allowing some drivers to see destinations in advance, to reject fares without reprisal, the ability to set a fare multiplier) did not fundamentally change that Uber is a transportation company. Had Prop 22 not passed, the company may nevertheless have been more successful in evading the ABC test in coming years as it grew into sectors beyond transportation, including financial services. ${ }^{32}$ The companies may have then

28. The application of the ABC test under Dynamex was limited to California wage orders which include both an hourly minimum wage protection (USD13 for employers with greater than 26 employees) and overtime protections (one and one-half times the employee's regular rate of pay for all hours worked in excess of eight hours up to and including 12 hours in any workday, and for the first eight hours worked on the seventh consecutive day of work in a work week; and double the employee's regular rate of pay for all hours worked in excess of 12 hours in any workday and for all hours worked in excess of eight on the seventh consecutive day of work in a work week).

29. California's ability to engage in affirmative field enforcement investigations is relatively new. In 2013, the Bureau of Field Enforcements (BOFE) was established under the Department of Labor Standards Enforcement in order to investigate industries in which low paid and unskilled workers may be enduring employment violations. The BOFE has the legal ability to audit employer's time and payroll records. To understand more about the BOFE, see https://www.dir.ca. gov/dlse/BOFE_Brochure.pdf.

30. Dubal, V. B. 'Wage Slave or Entrepreneur: Contesting the Dualism of Legal Worker Identities', Calif. L. Rev. 105 (2017): 65, 70 .

31. Dubal, V. B. 'Winning the Battle, Losing the War: Assessing the Impact of Misclassification Litigation on Workers in the Gig Economy', Wis. L. Rev. (2017): 739.

32. See, for example, my discussion of Uber's experiments with banking and with payday loans, in particular. Cf. Dubal, Veena, 'Uber's New Loan Program Could Trap Drivers in Crushing Debt', The Guardian. Dec. 5, 2019. Available at https://www.theguardian.com/commentisfree/2019/dec/05/uber-loan-program-debt. 
argued that 'the usual course' of their business was not mobility, but the facilitation of technologydriven transactions across any number of sectors. ${ }^{33}$ Still, labour platform companies, staffing agencies, franchisors, and multi-level marketing companies ${ }^{34}$ see the $\mathrm{ABC}$ test as a looming threat to the contingent labour they create and have come together to fight its spread. ${ }^{35}$

While Epic Systems undermines the possibility of class actions, keeps individual cases out of public courts, and thereby hinders the private enforcement of Dynamex, the implications of Dynamex decision were immediately apparent to the labour platform companies and to gig workers. Under the ABC test, analysts agree, there is little wiggle room; both on-demand and crowd-sourced labour platform workers were very likely to be considered employees under California state laws. ${ }^{36}$ Gig companies thus scrambled to leverage their significant structural and instrumental power to create a 'third category' legal carveout for themselves through legislation which would have exempted them from providing even basic protections. After the Dynamex decision, lawmakers spoke frequently about the importance of a 'compromise' between business and labour on the issue. In response to this general sentiment, two unions controversially began closeddoor conversations with the gig companies. ${ }^{37}$

Rather than wait for the companies to regulate themselves out of employment obligations, California Assemblywoman Lorena Gonzalez introduced a Bill in the 2019 legislative session now known as AB5. The Bill extended the legal precedent in Dynamex beyond wage orders to all California employment laws - including those in the Labour Code (which governs wage orders, meal and rest breaks, vehicle reimbursements and workers' compensation) and the Unemployment Insurance Code. The law also gave city attorneys the power to enforce the law through the issuance of an injunction, which means that if the companies did not comply, they could be held in civil contempt of court. ${ }^{38}$

While the media focus (and the focus of this article) with respect to AB5 has primarily been on the impact of the law for California' labour platform economy, the law extends to workers across industries, including the construction, janitorial, and salon industries, where misclassification has been a huge problem for decades. Because of claims that media and performance arts companies

33. This could be avoided in other contexts by redefining the ' $\mathrm{B}$ ' prong of the $\mathrm{ABC}$ test to account for this kind of diversification. For example, instead of analysing whether 'the worker performs work that is outside the usual course of the hiring entity's business', the legal test could examine whether 'the worker performs work that is outside the course of any part of the hiring entity's business'.

34. Multi-level marketing companies, like Amway, are often colloquially referred to as pyramid schemes in which direct sale companies use their existing salespeople to recruit new salespeople.

35. I use the term 'contingent labour' to refer broadly to work relationships that are insecure. In some cases, as with staffing agencies, the workers are defined as employees of the staffing agency, but not the main company. This often means the work is temporary and provides lower income. But in most cases, these workers are treated as independent contractors and paid by the piece. Notably, these companies that proliferate contingent labour have recently formed an industry alliance to fight back against the proliferation of the $\mathrm{ABC}$ test. For more information, see the website for the Coalition for Workforce Innovation at https://workforceinnovation.net/\#144a9c53-ed36-4890-9358-e1f048dcb8ce

36. We have seen much less policy debate in California on the subject of the application of AB5 to crowdworkers like Amazon Mechanical Turkers. This, perhaps, is because almost no one relies on AMT for their entire livelihood, and enforcement of employment laws to protect these workers seems less urgent. Additionally, unlike in-person on-demand service work, AMT work can be conducted anywhere in the U.S. A lawsuit or enforcement action would likely result in AMT shutting down California operations, sending AMT work to Turkers in other states.

37. Scheiber, Noam, 'Debate over Uber and Lyft Drivers' Rights in California Has Split Labour', The New York Times (2019). Available at https://www.nytimes.com/2019/06/29/business/economy/uber-lyft-drivers-unions.html.

38. Possible civil contempt sanctions including both monetary penalties and incarceration. 
were taking some of their jobs out of state to avoid classifying their workers as employees under California law, the California legislature amended AB5 in September 2020, exempting freelance writers and fine arts performers, among a select few other professions, from the ABC test. ${ }^{39}$ To date, no academic analysis has captured the labour market impact of AB5, but Assemblywoman Gonzalez's office has kept track of a number of businesses that have stopped misclassifying their workers (from yoga studios to private ambulance companies) in order to comply with the law. No conclusions can yet be drawn from this anecdotal data except that many businesses are complying with the law.

\section{Drivers take the lead: unprecedented organising in the gig economy}

During the earlier failure to regulate gig work by courts and legislatures, I interviewed a number of unhoused labour platform drivers who lived in their cars or who couch-surfed. They did not make enough to afford rent. Some of them had - at Uber's urging - purchased vehicles to work and were trapped in predatory auto loans. Other drivers I met (migrant workers) came up from Southern California and the Central Valley to drive where fares were higher. They were all exhausted from labouring under uncertain conditions. While not everyone wanted the control that they feared came with employee status, everyone wanted basic benefits like a wage floor and workers' compensation. ${ }^{40}$

Tired of relying on state actors and unions to fight on their behalf, a number of frustrated drivers started to organise. Drivers in Los Angeles, for example, founded an informal group that they called the Rideshare Drivers United (RDU) in 2018. Doing what some trade unionists thought was impossible as atomised and dispersed workers, RDU members built relationships through one-on-one conversations and weekly meetings. Because RDU is informally structured and does not collect dues, the group, unlike trade unions, can organise direct actions and fight for better wages without fear of anti-trust prosecution. ${ }^{41}$ It orchestrated actions to pressure state actors and even planned an unprecedented global strike against Uber and Lyft on May 8, 2019. In a remarkably short period of time and without funding, the RDU grew its membership to over 5000 workers and inspired affiliate grassroots groups in San Diego and San Francisco.

RDU and other drivers' groups, including those sponsored by unions and worker centres, readily endorsed AB5 and fought passionately to get it passed. The workers felt strongly that Uber and Lyft's proposed compromise legislation with labour unions was unsatisfactory. While the company's legislation included a wage floor, this floor did not account for driver waiting time (the time that a driver spends online, but without a work assignment). Thus, it still fell below the state minimum wage guarantee. The companies' proposal also did not account for overtime, unemployment insurance, or provide adequate workers' compensation. Instead, the proposal provided for a 'worker association' with limited powers to confer with the company and unspecified 'portable

39. See https://leginfo.legislature.ca.gov/faces/billTextClient.xhtml?bill_id=201920200AB2257

40. Dubal, V.B. 'An Uber Ambivalence: Employee Status, Worker Perspectives, \& Regulation in the Gig Economy' Beyond the Algorithm (Cambridge University Press, 2020).

41. Under federal anti-trust laws, companies could pursue an injunction against RDU, but they could not get any monetary remedies because the informal group does not have assets. Gig companies are further disincentivised from filing such a lawsuit against a group like RDU because they do not want to risk a decision on the merits finding workers to be employees under federal analysis. 
benefits'. ${ }^{42}$ The company would agree to fund the association and to meet with worker representatives, but it would not commit to bargaining over any substantive working conditions, including wages. In the U.S., if the drivers were found to be employees, such a company-influenced worker association would be illegal under the National Labor Relations Act. Advocacy from workers acting collectively ensured that AB5 passed the legislature without a 'compromise' or special carveout for labour platform companies.

\section{Post AB5: Covid-19 and enforcement attempts}

Anticipating that Governor Newsom would attempt to politically preclude the state of California from enforcing AB5 against the major labour platform companies, AB5 empowered city attorneys (who are politically independent from the Governor) to enforce the law. For many months after the law came into effect, however, neither the state nor the city attorneys filed suit. In private, government enforcers cited to a fear of being 'out-lawyered' and 'papered' by the labour platform companies. In response to the lack of enforcement of AB5, drivers with RDU launched a campaign on February 52020 that they called 'the People's Enforcement of AB5'. They organised more than 5000 Uber and Lyft workers from across the state to file individual complaints for back wages (including overtime and vehicle reimbursements) with the Labor Commissioner. These complaints alleged that hundreds of millions of dollars were owed to workers. In response, the Labor Commissioner's office filed an enforcement action against Uber and Lyft in August $2020 .{ }^{43}$

In March 2020, one month after these thousands of drivers filed individual complaints of wage theft under AB5, the Covid-19 pandemic arrived in California. As in many areas across the globe, the state of California issued lockdown orders, preventing many people in the retail sector from working. But labour platform workers, including those driving for Uber and Lyft and delivering food, fell under the category of essential workers. This meant that despite the state-wide lockdown, these people could expose themselves to the virus and continue to work. While demand increased for food delivery workers and grocery shoppers who worked for labour platforms, for transportation workers like Uber and Lyft drivers, demand was so low that working meant they lost money.

Because demand was very low and many drivers were scared to potentially expose themselves to the virus, many Uber and Lyft drivers filed for unemployment insurance. As per AB5, California owed these drivers state unemployment insurance as employees. However, the companies had not paid unemployment insurance taxes, nor had they provided the drivers' wage information to the state. This delayed the disbursal of funds to drivers. Meanwhile, Uber and Lyft barraged their drivers with misinformation, encouraging them to file for Pandemic Unemployment Assistance (PUA) instead of state unemployment insurance. The federal government provided PUA to independent contractors as an emergency stimulus measure. For Uber and Lyft drivers, the amount of PUA was substantially lower than what they were owed under state unemployment insurance. ${ }^{44}$

42. We know that these companies have contracted with a for-profit company called Workers Benefits Fund. The portable benefits that the company hopes to profit from and provide fall well below the benefits that employees are provided under state and federal employment laws.

43. See https://www.dir.ca.gov/DIRNews/2020/202065.html\#: :text=\%E2\%80\%9CThe\%20Uber\%20and $\% 20 \mathrm{Lyft} \%$ 20business,as $\% 20$ overtime $\% 20$ and $\% 20$ minimum $\% 20$ wages. $\%$ E2\%80\%9D

44. For example, a Lyft driver with a gross income of USD45,750, and after accounting for expenses, a net income of USD21,437, was owed USD440 per week under the California state unemployment insurance programme, but only USD207 per week under the federal pandemic unemployment assistance programme intended for independent contractors. 
Still, confused by the companies and desperate to quickly receive their unemployment checks, most drivers in California filed for PUA.

The crisis of Covid-19 highlighted the precarity of labour platform work. On the one hand, Uber and Lyft drivers were essential workers by law. On the other, many were not making a minimum wage and unable to navigate the unemployment system. A number of news stories and essays, including my own, emphasised how Uber and Lyft drivers were experiencing 'a crisis on top of a crisis'. ${ }^{45}$ Drivers could not make their car payments or insurance payments. A growing number of them were food and housing insecure, and as immigrants, some of these drivers did not know where to turn for state support to access food stamps.

The pandemic, combined with the 5000 complaints filed by Uber and Lyft drivers alleging wage theft, catalysed state enforcement of AB5. On 5 May, the California Attorney General Xavier Becerra announced that his office, alongside the San Diego, Los Angeles, and San Francisco City Attorneys' Offices, had filed suit against Uber and Lyft for violation of AB5. They later filed for an injunction to force the companies to immediately comply with the law. In court, Uber and Lyft attorneys maintained - as they had in litigation across the globe - that the companies were platform companies and not transportation companies. Thus, the argument went, the drivers were doing work outside 'the usual scope' of Uber and Lyft's core business. In a sharply worded decision, Superior Court Judge Ethan Schulman issued the injunction, holding that the companies were in violation of AB5 and had to immediately comply with employment laws. ${ }^{46}$ The companies appealed, and on 22 October 22, a California appellate court affirmed the injunction, siding with the Superior Court in finding that the state and city attorneys were very likely to succeed on the merits in arguing that Uber and Lyft drivers are employees of their companies. Nevertheless, due to the passage of Prop 22 only 19 days later, the companies never complied with the law.

\section{The anti-democratic passage of Proposition 22}

In response to the passage of AB5 and attempts at its enforcement, Uber, Lyft, DoorDash, Postmates, and Instacart invested a record USD203 million in Proposition 22. In California, with enough signatures from voters, laws can be placed on the ballot for a direct vote from the electorate during the general election. These propositions, or initiatives, cannot be overturned by the California legislature but only by another proposition. ${ }^{47}$

Prop 22 was written as a referendum on AB5 for Delivery Network Companies and Transportation Network companies (defined in footnote 21 above). It exempted the companies from complying with California labour and employment laws and sanctioned a piece-pay system in which workers are only paid for 'engaged time' - when the company disseminates work to them (see footnote 22 for definition of engaged time). It also leaves the costs associated with driving, including vehicle depreciation, gas, and insurance, unreimbursed. Economists have

45. Dubal, Veena and Meredith Whittaker, 'Uber Drivers are Being Forced to Choose Between Risking Covid-19 and Starvation', Mar. 25, 2020. Available at https://www.theguardian.com/technology/2020/mar/25/uber-lyft-gigeconomy-coronavirus.

46. See https://assets.documentcloud.org/documents/7032764/Judge-Ethan-Schulman-Order-on-Lyft-and-Uber.pdf

47. Studies of California' system of direct democracy suggest that system has constrained the ability of the legislature to govern and shifted power from elected legislators to organised, powerful interest groups, including corporations. California law does not constrain the amount of money that can be spent on propositions, nor does it make false or misleading political advertising illegal. 
calculated that as a result, the hourly minimum wage for gig workers under this proposition would be USD5.64, or roughly one third of the minimum wage of the city of San Francisco. ${ }^{48}$ By contrast, under AB5, gig workers would be entitled to the minimum wage for each hour, or fraction thereof, that they work, even if they spend most of that time awaiting a fare. After the passage of Prop 22, DNC and TNC workers do not have access to paid family leave, paid sick leave, workers' compensation, unemployment insurance, protection from retaliation, or health and safety protections (see Table 2).

Proposition 22 has been widely criticised as anti-democratic for two primary reasons. First, the proposition is nearly impossible to amend. As per the language of the law, any legislation that would give TNC and DNC workers any protections - even emergency paid sick leave in the context of a pandemic - would take a vote by $7 / 8$ of the California legislature. Thus, the initiative effectively constrains elected legislators from passing laws. Second, as discussed above, the campaign to pass the proposition engaged in a plethora of false and misleading advertising to influence the electorate. Television commercials, for example, alleged that Proposition 22 would give Uber and Lyft drivers a minimum wage. The companies paid for methodologically flawed 'studies' alleging that workers wanted to be independent contractors. The companies also alleged that thousands of Californians would lose their jobs as a result. Independent economics studies showed that, in fact, the vast majority of work was conducted by full-time drivers and that the companies would continue to use part-time drivers, and that employment laws would force the companies to better calibrate supply and demand so that workers could actually earn a living. ${ }^{49}$ But voters were overwhelmed by texts, in-app messages, emails, and online ads alleging that the majority of workers wanted Proposition 22 to pass. As a result, the $58 \%$ of California voters who voted in favour of the proposition may have been misled or misunderstood what they were voting for.

\section{Looking Forward: using federal Law and employment Status to organise for a democracy}

While legal challenges based on the constitutionality of Prop 22's 7/8 amendment provision are considered, what lies ahead for the regulation of labour platforms in California and the U.S.? Given the inability of the California legislate to regulate in the area of TNC and DNC worker protections, what future do California's TNC and DNC workers have?

TNC and DNC workers can no longer challenge their independent contractor status under state law, but they may be able to do so under federal law. One promising path forward may be for drivers' groups (like RDU mentioned above) to continue to build collective power and to eventually file for union recognition under federal labour law, with the hope that the federal

48. Jacobs, Ken and Michael Reich, ‘The Uber-Lyft Ballot Initiative Guarantees Only \$5.64 an Hour', UC Berkeley Labour Center, October 31, 2019. Available at http://labourcenter.berkeley.edu/the-uber-lyft-ballot-initiative-guarantees-only5-64-an-hour/

49. Reich, Michael, 'Pay, Passengers, and Profits: Effects of Employee Status for California TNC Drivers', Institute for Research on Labour and Employment Working Paper \#107-20. October 2020. Available at https://irle.berkeley.edu/ files/2020/10/Pay-Passengers-and-Profits.pdf. Uber's own data from 2016, when wages were much higher, found that $68 \%$ of people who sign up to drive for Uber quit after three months. Cf. Brown, Eliot, 'Uber and Lyft Face Hurdle of Finding and Keeping Drivers', Wall Street Journal (2019). Available at https:/www.wsj.com/articles/uber-andlyft-face-tough-test-of-finding-and-keeping-drivers-11557673863. Thus, the number of people that the companies said would lose their 'jobs' was greatly exaggerated because it included Californians who had stopped driving voluntarily. 
body that grants union status (National Labor Relations Board) will find them to be employees for purposes of collective bargaining. While Trump's NLRB General Counsel Robb issued a non-binding advisory opinion calling Uber drivers independent contractors, carved out of the NLRA,${ }^{50}$ federal analysis on the issue would certainly change under a different general counsel. Robb's memo, which applies the 'entrepreneurial potential' test to Uber drivers, has been widely decried as political and not legal analysis because it ignores the many ways in which workers' wages, allocation of fares, and total hours are algorithmically controlled, thus belying true entrepreneurial potential.

Another path forward, already articulated by the Biden administration, is to create a federal standard modelled on $\mathrm{AB} 5$, using the $\mathrm{ABC}$ test to determine employee status for all labour, employment, and tax laws. As federal law, such a standard would preempt Proposition 22. If such a law were to pass, in an ironic twist, the so-called 'gig economy' could be a political catalyst for both worker-led organising and the revitalisation of labour law.

As this possibility is being considered, however, the labour platform companies have created alliances with other corporate sources of contingent labour, including staffing agencies (like Kelly Services) and multi-level marketing companies (like Amway), to form a Coalition for Workforce Innovation. Their goal is specifically to fight the $\mathrm{ABC}$ test vigorously at both state and federal levels. Using the Prop 22 misinformation campaign as a blueprint, they have begun to introduce and advertise similar laws in states across the U.S., including New York, Massachusetts, and Illinois. The vociferous industry fight against the ABC test and California's AB5 reveals the extent to which the test itself (when enforced) is legally effective in fighting the misclassification of workers.

As the U.S. economy faces an era of historic inequality and high unemployment, it will also face growing attempts to casualise middle-class work. The economic threats posed by labour platform work are no longer limited to a few sectors. Venture capitalists, emboldened by the passage of Prop 22, have articulated their desire to expand their model of insecure labour platform work to other industries, including healthcare, education, computer programming, and retail. $^{51}$

The lessons learned in California through AB5 and Prop 22 are key to fighting these potential trends. Industrialists bent on lowering labour costs through the piece-pay system sanctioned by Prop 22 correctly understand the ABC test as an existential threat. And, like tobacco companies and agricultural companies before them, they will continue to aggressively deploy misinformation campaigns and flawed, corporate-sponsored research to lobby against the $\mathrm{ABC}$ test and any regulations that require that they provide a living wage and basic safety net protections to their workers. In local, federal, and international debates about the future of work and workers, labour platform work must be understood not as a niche sector but as a fundamental threat to both economic security specifically and democracy more broadly.

50. Scheiber, Noam, 'Uber Drivers are Contractors, Not Employees, Labour Board Says', The New York Times (2019). Available at https://www.nytimes.com/2019/05/14/business/economy/nlrb-uber-drivers-contractors.html

51. Carolan, Shawn, 'What Proposition 22 Makes Possible', The Information. November 10, 2020. Available at https:// www.theinformation.com/articles/what-proposition-22-now-makes-possible . 